\title{
Welfare Evaluation of the Duck Breeding in Gandus Subdistrict, Palembang
}

\author{
Marieska Lupikawaty ${ }^{1, *}$ Neneng Miskiyah ${ }^{1}$ Purwati Purwati ${ }^{1}$ \\ Keti Purnamasari ${ }^{1}$ Julito Contado Aligaen ${ }^{2}$ M Fadhil Amiros ${ }^{1}$ M R afi Fahriza ${ }^{1}$ \\ ${ }^{1}$ Business Management Study Program, Department of Business Administration, Sriwijaya State Polytechnic \\ ${ }^{2}$ Social Science Department, Iloilo Science, and Technology University Philippines \\ ${ }^{*}$ Corresponding author. E-mail:marieska@polsri.ac.id
}

\begin{abstract}
The Department of Agriculture and Food Security of Palembang City is located in the Gandus sub-district, assisting in the form of ducks breeders to reduce poverty and improve community welfare. Methods of data collection using questionnaires and interviews with duck farmers. The number of samples as many as 68 people with the census sampling technique method. Data analysis method using SmartPLS with PLS Algorithm and Bootstrapping test. The results of data processing show that the assistance of ducks to farmer groups in Gandus sub-district has not been successful in increasing income and welfare. The income of duck farmers is not from selling duck eggs but from other sources of income. The factors that cause the failure of duck breeders are i) lack of experience of duck breeders in raising ducks, ii) inappropriate breeder environment because ducks can survive in paddy fields and swampy land so that the ducks can find their food. It is recommended that the Department of Agriculture and Food Security of Palembang City should provide laying hens assistance to farmer groups because it is under the experience of farmers and the breeder's environments.
\end{abstract}

Keywords: welfare, poverty alleviation, income, farmer groups, smart PLS

\section{INTRODUCTION}

The Government of the Republic Indonesia through the Ministry of Agriculture has a program in an effort to alleviate poverty so that people are more prosperous. One of the programs that have been launched is BEKERJA Program or the Welfare People's Poverty Surgery based on agriculture. The BEKERJA program provides assistance to households in the form of livestock and plants that use community yards intensively for agriculture. The government's hope, in this case the ministry of agriculture, is that there is good synergy from all parties, both the government, stakeholders, organizations from the community and from academia [1].

\subsection{Background of the problem}

The BEKERJA program has also been carried out by the Department of Agriculture and Resilience of the City of Palembang, which is located in Gandus District. In 2017 it has distributed ducks, cage materials, and duck feed for 1 month. The Department of Agriculture and
Resilience of the City of Palembang also continues to provide business assistance by deploying Field Extension Officers (PPL) every day and periodically vaccinating animals.

The selection of assistance in the form of ducks to the community for reasons according to the geographical conditions in the Gandus sub-district, namely swampy land. Based on interviews that have been conducted with veterinary authority officials, Dr.Drh.Jafrizal that there will be no similar activities until 2020 because the results of the assistance are still being observed, so assistance from academics is needed to evaluate the impact of the duck distribution assistance. Programs that have been running can be said to be successful if the indicators of success are that ducks can lay eggs and ducks can breed so as to provide income for farmers which can further reduce poverty and improve welfare. Poverty is a condition of limited ability to meet the needs of a decent life, while welfare is the level of poverty condition of a household. The cause of poverty leads to the vicious cycle of poverty theory proposed by Nurkse in [2], that market imperfections, and lack of capital lead to low 
productivity. Low productivity results in low income received. Low income will have implications for low savings and investment. low investment results in underdevelopment and poverty.

\subsection{Research purposes}

This study attempts to evaluate the distribution of poverty alleviation program assistance in the form of ducks from the Department of Agriculture and Food Security of Palembang City.

\section{LITERATURE REVIEW}

\subsection{Poverty}

Poverty is a condition of limited ability to meet the needs of a decent life such as limitations in the ownership of household resources. Implies from [3] that resources consist of natural resources, human resources and capital resources. This measurement is material or monetary approach. Measurement with a monetary approach can be done using expenditure data as an approach to household income [4].

\subsection{Income}

Income has a close relationship with the level of production achieved, if production increases then income tends to increase. In addition, the income of farmers depends on the prevailing price level. The level of income is influenced by production and price levels. According to the book on Duck Cultivation Techniques [5], the productivity of ducks is influenced by factors 1) quality of seeds, 2) maintenance procedures, 3) quality and method of feeding, 4) business systems and financial analysis and 5) experience in maintaining.

\subsection{Investment}

Investment can be defined as a commitment of a sum of money or other resources made at this time (present time) with the hope of obtaining benefits in the future. At the practical level, investment is usually associated with various activities related to investing money in various alternative assets, both classified as real assets such as land, gold, property or in the form of financial assets, such as various forms of letters. valuables such as stocks, bonds or mutual funds [6].

\subsection{Welfare}

Welfare is the level of poverty condition of a household. Based on the Poverty Line indicator [7], a family is said to be poor or less prosperous if it has per capita expenditure per month below the poverty line of Rp 521,489,--.

\section{METHODOLOGY}

The data needed for this research, using the method of library research and field research. The data collection method used by the team was to conduct a structured oral question and answer session with the staff and leaders responsible for the livestock business household poverty alleviation program from the Agriculture and Resilience Office of Palembang City. Furthermore, distributing questionnaires with the heads of livestock business households who have received assistance from the Palembang City Agriculture and Food Security Service.

Table 1 Population Distribution of Farmer Group Assistance in Gandus District

\begin{tabular}{|c|c|c|c|c|c|}
\hline \multicolumn{5}{|c|}{ Pegagan Duck Breeding Group } & Total \\
\hline $\begin{array}{l}\text { Sinar } \\
\text { Lestari }\end{array}$ & $\begin{array}{l}\text { Sinar } \\
\text { Jaya }\end{array}$ & $\begin{array}{l}\text { Sri } \\
\text { Kembang }\end{array}$ & $\begin{array}{l}\text { Kerto } \\
\text { wijaya }\end{array}$ & $\begin{array}{l}\text { Sandang } \\
\text { Sarana }\end{array}$ & \\
\hline 15 & 10 & 23 & 10 & 10 & 68 \\
\hline
\end{tabular}

Source: Department of Agriculture and Food Security of Palembang City, 2019 [8]

The population was taken from the number of duck breeders who had been assisted by the Palembang City Agriculture and Food Security Service, namely 68 people. A sample is a certain sample taken from a population and examined in detail. Due to the population below 100 people, the sampling technique that can be used is the census sampling technique, which is a study conducted on all members of the population [9], so the number of samples is 68 people.

The methods and analysis used in making the livestock business household poverty alleviation model with SEM PLS modeling analysis with data analysis steps such as quotes from [10].

\section{RESULT AND DISCUSSION}

\subsection{Measurement Evaluation (Outer) Model}

Data analysis using SmartPLS with PLS Algorithm and Bootstrapping test. The outer model can be evaluated through three criteria, namely 1) convergent validity, 2) discriminant validity, 3) composite reliability. Convergent validity tests the correlation between items/indicators and their construct scores. To test the validity of the items from the questionnaire using the outer loading test from the PLS Algorithm. The following are the results of the instrument test: 
Table 2 Outer Loading

\begin{tabular}{|l|l|l|l|l|l|}
\hline & Invest & Poverty & Welfare & Consump & Income \\
\hline X1 & & 0.664 & & & \\
\hline X2 & & 0.785 & & & \\
\hline X3.1 & & -0.012 & & & \\
X3.2 & & 0.139 & & & \\
X3.3 & & 0.025 & & & \\
X3.4 & & 0.378 & & & \\
X3.5 & & -0.053 & & & \\
X3.6 & & 0.179 & & & \\
\hline X4 & & 0.615 & & & \\
\hline X5.2 & & & & & 0.119 \\
\hline X6.2 & & & & & 1,000 \\
\hline X7 & & & & -0.974 & \\
\hline X8 & & & & -0.238 & \\
\hline X9 & 0.629 & & & & \\
\hline X10 & 0.836 & & & & \\
\hline Y1 & & & 0.776 & & \\
\hline Y2 & & & 0.955 & & \\
\hline
\end{tabular}

Individual reflection size is said to be high if the correlation is more than 0.70 , but according to Chin in [11] for research in the early stages of developing a measurement scale for the loading factor value of 0.5 to 0.6 is considered sufficient. From Table 1, it can be seen that the results of the loading factor test which have results above 0.5 , namely indicators $\mathrm{X} 1, \mathrm{X} 2, \mathrm{X} 4, \mathrm{X} 6.2$, $\mathrm{X} 9, \mathrm{X} 10, \mathrm{Y} 1$ and $\mathrm{Y} 2$, while results below 0.5 can be deleted and processed data return.

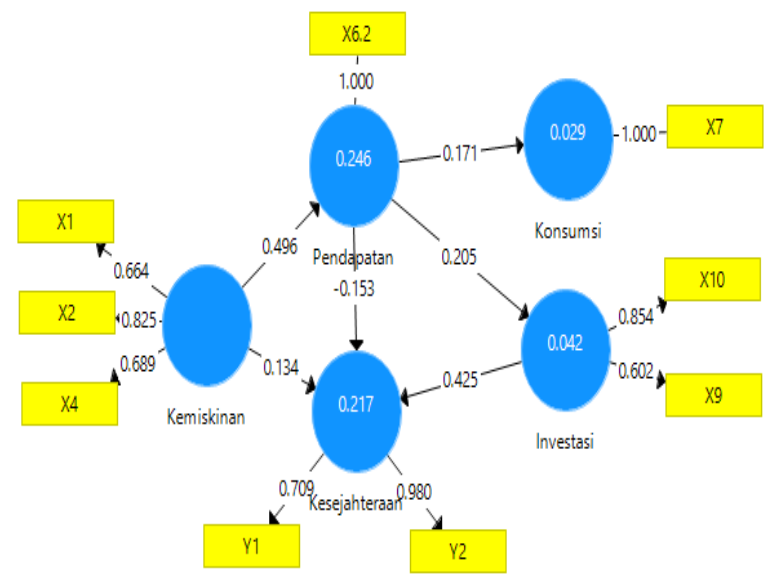

Figure 1 Poverty Reduction Model

After removing the results from the loading factor test below 0.5 , Figure 1 is a model where the results have met convergent validity because all factor loadings are above 0.5 .

Discriminant validity purposes to predict the size of one block rather than the size of the other. Evaluation of the discriminant validity measurement model can be seen from the value of the Average Variance Extracted (AVE) it is recommended that it must be above 0.50 .
Table 3 Variable AVE Value

\begin{tabular}{|l|l|l|}
\hline Variable & AVE & Information \\
\hline Investment & 0.546 & Valid \\
\hline Poverty & 0.532 & Valid \\
\hline Income & 1,000 & Valid \\
\hline Consumption & 1,000 & Valid \\
\hline Well-being & 0.731 & Valid \\
\hline
\end{tabular}

Information in Table 2 shows that the AVE value is above 0.50 for all variables, meaning that the variance of the indicator can be explained as much as $50 \%$ or more, so that it is in accordance with the model's assessment criteria.

Composite reliability purposes to measure the extent to which the measuring instrument can be trusted (reliable), measuring internal consistency and the value must be above 0.60 . With the composite reliability criteria in the PLS Algorithm test, the following results are obtained:

Table 4 Composite Reliability

\begin{tabular}{|l|l|l|}
\hline Variable & $\begin{array}{l}\text { Composite } \\
\text { Reliability }\end{array}$ & Information \\
\hline Investment & 0.700 & Reliable \\
\hline Poverty & 0.772 & Reliable \\
\hline Income & 1,000 & Reliable \\
\hline Consumption & 1,000 & Reliable \\
\hline Well-being & 0.841 & Reliable \\
\hline
\end{tabular}

Information in Table 3, it can be seen that all variables above 0.60 have met the reliable element, meaning that the questionnaire questions are consistent.

\subsection{Evaluation of the Structural Model (Inner Model)}

In assessing the model with PLS, you can see the Rsquare for each dependent latent variable. Changes in the value of R-square can be used to assess the effect of certain independent latent variables on the dependent latent variable whether it has a substantive effect.

Table 5 R-Square Nilai Value

\begin{tabular}{|l|l|l|}
\hline Variable & R-Square & Information \\
\hline Investment & 0.042 & Weak \\
\hline Income & 0.246 & Weak \\
\hline Consumption & 0.029 & Weak \\
\hline Well-being & 0.217 & Weak \\
\hline
\end{tabular}

According to [11] R-square results of $0.67,0.33$ and 0.19 for endogenous laten variables in the structural model indicate that the model is categorized as good, moderate and weak. The information in Table 4 of the calculation results shows the model is categorized as low. 


\subsection{Hypothesis test}

Hypothesis testing using bootstrapping method. This hypothesis test is done by analysing the pvalue. The criterion for testing the hypothesis is the p-value with a significant level of 5\%.

Table 6 P-value

\begin{tabular}{|l|l|l|l|l|l|}
\hline & $\begin{array}{l}\text { Original } \\
\text { Sample }\end{array}$ & $\begin{array}{l}\text { Standard } \\
\text { Deviation }\end{array}$ & $\begin{array}{l}\text { T- } \\
\text { Statistics }\end{array}$ & $\begin{array}{l}\text { P- } \\
\text { Values }\end{array}$ & Decision \\
\hline $\begin{array}{l}\text { Investm } \\
\text { ent }-> \\
\text { Welfare }\end{array}$ & 0.425 & 0.114 & 3,744 & 0.000 & $\begin{array}{l}\text { Accept } \\
\text { ed }\end{array}$ \\
\hline $\begin{array}{l}\text { Poverty } \\
-> \\
\text { welfare }\end{array}$ & 0.209 & 0.132 & 1,587 & 0.113 & $\begin{array}{l}\text { Rejecte } \\
\mathrm{d}\end{array}$ \\
\hline $\begin{array}{l}\text { Poverty } \\
-> \\
\text { income }\end{array}$ & 0.496 & 0.166 & 2,978 & 0.003 & $\begin{array}{l}\text { Accept } \\
\text { ed }\end{array}$ \\
\hline $\begin{array}{l}\text { Income - } \\
> \\
\text { investm } \\
\text { ent }\end{array}$ & 0.205 & 0.245 & 1.809 & 1.809 & $\begin{array}{l}\text { Rejecte } \\
\mathrm{d}\end{array}$ \\
\hline $\begin{array}{l}\text { Income- } \\
> \\
\text { welfare }\end{array}$ & -0.240 & 0.124 & 1,935 & 0.054 & $\begin{array}{l}\text { Rejecte } \\
\mathrm{d}\end{array}$ \\
\hline $\begin{array}{l}\text { Income - } \\
> \\
\text { consum } \\
\text { ption }\end{array}$ & 0.171 & 0.144 & 1.078 & 0.282 & $\begin{array}{l}\text { Rejecte } \\
\mathrm{d}\end{array}$ \\
\hline
\end{tabular}

The results of the calculations in Table 5 are concluded:

1. Investment on welfare has a positive and significant effect because $t$ statistic $>t$ table is $3,744>1.96$ or significant below 0.05

2. Poverty on welfare has an insignificant effect because $\mathrm{t}$ statistic $<\mathrm{t}$ table is $1.587<1.96$ or significant above 0.05

3. Poverty on income has a positive and significant effect because the $\mathrm{t}$ statistic $>\mathrm{t}$ table is $2,978>1.96$ or the significance is below 0.05

4. Income on investment has no significant effect because $\mathrm{t}$ statistic $<\mathrm{t}$ table is $1.809<1.96$ or significant above 0.05

5. Income against kWelfare has an insignificant effect because $\mathrm{t}$ statistic $<\mathrm{t}$ table is $1.935<1.96$ or significant above 0.05

6. Income on consumption has no significant effect because $\mathrm{t}$ statistic $<\mathrm{t}$ table is $1.078<1.96$ or significant above 0.05

\section{AUTHORS' CONTRIBUTIONS}

The results of data processing show that the assistance of ducks to farmer groups in Gandus sub-district has not been successful in increasing income and welfare because income has no effect on welfare. The income of duck farmers is not from selling duck eggs but from other sources of income.

The factors that cause the failure of duck breeders are i) lack of experience of duck breeders in raising ducks, ii) inappropriate breeder environment because ducks can survive in paddy fields and swampy land so that the ducks can find their food.

It is recommended that the Department of Agriculture and Food Security of Palembang City should provide laying hens assistance to farmer groups because it is under the experience of farmers and the breeder's environment.

\section{ACKNOWLEDGMENTS}

The author is grateful to the Director of the Sriwijaya State Polytechnic through the P3M Polsri implementation unit for the funding assistance for the overseas collaboration assignment scheme research 2021.

\section{REFERENCES}

[1] Maroli, "Kementerian Komunikasi dan Informatika," 2018.

[2] M. Kuncoro, Ekonomi Pembangunan (Teori, Masalah, Dan kebijakan (Edisi Ke empat). Yogyakarta: UPP STIM YKPN, 2006.

[3] I. SP, "Teori Ekonomi Mikro.pdf." Gunadarma, Jakarta, pp. 1-248, 1994

[4] W. Isdijoso and A. Suryahadi, "Penetapan Kriteria dan Variabel Pendataan Penduduk Miskin yang Komprehensif dalam Rangka Perlindungan Penduduk Miskin di Kabupaten / Kota."

[5] Y. Sukmaya dan Rismayanti, Petunjuk Teknis Budidaya Ternak Itik, vol. 1. Lembang, Jawa Barat: PUAP BPTP Jabar, 2010.

[6] E. Tandelilin, "Dasar-dasar Manajemen Investasi," Manaj. Investasi, pp. 1-34, 2012.

[7] Badan Pusat Statistik, "Badan Pusat Statistik," 2017.https://palembangkota.bps.go.id/subject/23/k emiskinan.html\#subjekViewTab1.

[8] Dinas Pertanian dan Ketahanan Pangan Kota Palembang, "Bantuan Program Pengentasan Kemiskinan Masyarakat Miskin Kecamatan Gandus," Palembang, 2019.

[9] H. E. Puteri, "Menentukan Populasi dan Sampel," Ris. Ekon. dan Perbank. Islam, no. April, pp. 1-6, 2020, doi: 10.13140/RG.2.2.28776.01285.

[10] F. A. Alodya Ann Gita Alfa, Dewi Rachmatin, "Analisis Pengaruh Faktor Keptusan Konsumen Dengan Struktural Equation Model Partial Least Square," Eureka Matika, Vol. 5, No.2, 2, pp. 59-71, 2017.

[11] I. Ghozali, Struktural Equation Modeling Metode Alternatif dengan Partial Least Square (PLS). Semarang: Universitas Diponegoro, 2006. 